\title{
Effect of size sorting on growth, cannibalism, and survival in Eurasian perch Perca fluviatilis L. post-larvae
}

\author{
Jarosław Król ${ }^{1}$ (D) $\cdot$ Artur Długoński $^{1}$ • Maciej Błażejewski ${ }^{1} \cdot$ Piotr Hliwa ${ }^{1}$ \\ Received: 5 November 2018 / Accepted: 28 December 2018 / Published online: 9 January 2019 \\ (C) The Author(s) 2019
}

\begin{abstract}
The effect of size sorting on rearing effectiveness in Eurasian perch post-larvae was evaluated. A 34-day-old perch were reared for 2 weeks in three experimental groups as a small size group (SM, mean weight $0.061 \pm 0.011 \mathrm{~g}$ ), large size group (SL, mean weight $0.148 \pm 0.024 \mathrm{~g}$ ), and unsorted group (US, mean weight $0.105 \pm 0.048 \mathrm{~g})$ in recirculating aquaculture system $\left(21^{\circ} \mathrm{C}\right.$; $12 \mathrm{~L}: 12 \mathrm{D})$. At the end of the experiment, specific growth rate $\left(\%\right.$ day $\left.^{-1}\right)$ was significant greater $(P<0.05)$ in SM $(9.48 \pm 0.34)$ than SL $(6.95 \pm 0.40)$ and US $(8.35 \pm 0.60)$; however, significant size rank correlations (initial weight vs. final weight) were maintained in all experimental groups $\left(r_{\mathrm{sp}}>0.77\right)$. Fish biomass gain $(\%$ of IBs) were significant higher $(P<0.05)$ in both sorted groups $344 \pm 29$ and $256 \pm 6$ for SM and SL, respectively than US (233 \pm 10$)$, which directly resulted from higher survival in sorted groups (>90.0\%) than US (75.6\%). Difference in observed survival rates resulted from significant lower losses to type I cannibalism in both sorted groups, 4.3 and $3.2 \%$ for SM and SL, respectively than in US $(>18.0 \%)(P<0.05)$. It is concluded that the size sorting of Eurasian perch post-larvae has a positive impact on the rearing effectiveness, measured as significant higher biomass gain, directly resulting from higher survival, trough lower losses caused by cannibalism type I.
\end{abstract}

Keywords Cannibalism · Growth $\cdot$ Perch $\cdot$ Size sorting $\cdot$ Survival

\section{Introduction}

Eurasian perch (Perca fluviatilis) is considered among the most promising species for possible intensive fish farming in Europe (Teletchea and Fontaine 2014; Toner 2015). Despite progress in the know-how methodology of aquaculture production of this species in the last two decades, further development of commercial production has been still restricted due to the

Jarosław Król

krolas@uwm.edu.pl

1 Department of Ichthyology, University of Warmia and Mazury in Olsztyn, Warszawska 117A street, 10-719 Olsztyn, Poland 
low possibility of control over the reproduction and high unpredictability of stocking material quality (Żarski et al. 2015; Kestemont et al. 2015). Therefore, one of the key to the further development of the perch production is to optimize conditions for rearing both, the larval and the juvenile stages. It has been recognized as one of the main bottlenecks in the perch aquaculture, mainly because of high intra-cohort cannibalism and mortality resulting from problems with swim bladder inflation and non-feeding behavior (Baras et al. 2003; Kestemont et al. 2003; Babiak et al. 2004; Król and Zieliński 2015). The cannibalism occurs in many cultured fish species, including non-predatory species; however, it is most prevalent in piscivorous taxa, especially at larval and juvenile stages (Smith and Reay 1991; Hecht and Pienaar 1993; Baras and Jobling 2002; Król et al. 2014). In farmed percid fish species, intracohort cannibalism is an important issue induced losses exceeding $50 \%$ of the initial stocking density during the first weeks of rearing (Baras et al. 2003; Kestemont et al. 2003; Babiak et al. 2004; Hamza et al. 2007; Kestemont et al. 2007; Król et al. 2015; Król and Zakęś 2016). Intracohort cannibalism is mainly caused by size heterogeneity of larvae, which is usually affected by multiple interactive and non-interactive factors such as the environment and population structure (Kestemont et al. 2003). High size variation can facilitate the emergence of cannibalism. However, the dynamics of growth, size dispersal, and cannibalism in cultured fishes can be complex (Baras and Jobling 2002). At least, one previous study in perch reported that the size dispersal could have some unexpected positive effects, as it prevents the emergence of new cannibals, thereby reducing the overall impact of cannibalism (Mandiki et al. 2007).

Size sorting is a common procedure which is used during intensive juvenile fish rearing in order to reduce size variations in the cohort and to improve growth and survival (Sunde et al. 1998; Wallat et al. 2005). The main idea behind size grading is to separate small and large individuals from each other to avoid potentially negative effects of social interactions and to mitigate the impact of cannibalism (Jobling 1995). Moreover, in aquaculture industry, good practices usually aim to minimize fish size heterogeneity over the time in order to improve feeding efficiency through adequate food ration and further benefit based on minimizing growth dispersion, yielding greater stocks of marketable fish at the same time (Kestemont et al. 2003; Petrović et al. 2011). The positive effects of size grading on the growth of juvenile Atlantic salmon, Salmo salar (Gunnes 1976) sea bream, Sparus aurata (Popper et al. 1992), Nile tilapia, Oreochromis niloticus (Brzeski and Doyle 1995), and European sea bass, Dicentrarchus labrax (Batzina et al. 2018) have already been reported. In the other hand, there are reports indicating that growth rate was not improved in size-graded groups compared with non-sorted groups of several fish species (Baardvik and Jobling 1990; Sunde et al. 1998; Barki et al. 2000; Wallat et al. 2005; Imsland et al. 2009). The usefulness of size sorting procedure in European cultured percids is under debate; however, in percid fish farms, it is carried out routinely (Policar et al. 2015). The sorting procedure of pikeperch (Sander lucioperca) larvae has a positive impact on the survival rate; however, it has no effect on growth during their rearing in culture trial (Szczepkowski et al. 2011). Contrary, size sorting of juvenile pikeperch did not improve the rearing effectiveness of this species (Zakesś et al. 2004). The usefulness of size sorting practices at the larval stage in Eurasian perch is questionable, except for the initial sorting based on hatching time (Kestemont et al. 2015). This statement was based on that initial size heterogeneity of the larvae had very little influence on final size heterogeneity of the post-larvae and cannibalism in the perch cohort (Kestemont et al. 2003; Babiak et al. 2004). Moreover, sorting on juvenile perch caused the productivity to be slightly lower (5-6\%) (Mélard et al. 1996). It should be emphasized that only very few studies were done to understand size sorting effects on perch post-larvae. 
Therefore, the present study was designed to investigate the effect of size sorting on growth, survival, and cannibalism in Eurasian perch post-larvae under controlled conditions.

\section{Material and methods}

\section{Origin of larvae and preliminary experimental conditions}

Eurasian perch (Perca fluviatilis L.) breeders were captured in Sasek Wielki Lake (NE Poland) during commercial catches using fyke nets in early April. After catching, the fish were immediately transported (in polyethylene bags containing $30 \mathrm{~L}$ of water; approx. $60 \%$ of total volume of the bag consisted of mostly pure oxygen atmosphere) to the recirculating aquaculture systems (RAS) in Aquaculture and Ecological Engineering Center, University of Warmia and Mazury in Olsztyn, Poland. The gametes of perch were obtained in accordance with the previously established procedure (Źarski et al. 2011). Egg-ribbons from two females were fertilized with pooled semen of four males. Fertilized eggs were incubated in a flow-through water recirculating system at $14{ }^{\circ} \mathrm{C}$. Just before hatching, ribbons were placed in $500-\mathrm{L}$ tank at $17^{\circ} \mathrm{C}$. Eggs started to hatch on day 8th post fertilization. After $24 \mathrm{~h}$ from the first hatching, ribbons with unhatched embryos were removed from the tank. Larvae were reared in the same tank for the next 33 days. Temperature was progressively increased to $21^{\circ} \mathrm{C}$ and dissolved oxygen was maintained to saturation at $8.5 \mathrm{mg} \mathrm{L}^{-1}$. Larvae were exposed to a photoperiod $16 \mathrm{~L}: 8 \mathrm{D}$, and the light intensity $75 \mathrm{~lx}$ measured just above the tank water surface. Before the experiment, from 5 to 15 days after hatching (dph), larvae were fed ad libitum by hand with mixed Artemia sp. naupli (INVE, Belgium) and commercial formulated diet (Perla Larva Proactive 5.0, Trouvit Nutreco, Holland) six times a day (8:00, 10:00, 12:00, 14:00, 17:00, and 20:00). Further, larvae were exclusively fed with Perla Larva Proactive 5.0 for the next 7 days of the rearing, then they were gradually switched to Perla Larva Proactive 4.0 to the 33 th dph. According to the producer, both formulated diets contained $62 \%$ protein, $11 \%$ lipid, and $10 \%$ carbohydrates.

\section{Experimental design, data collection, and analysis}

Two weeks experiment was conducted with perch aged $34 \mathrm{dph}$. The study was carried out with three experimental groups in triplicate. Small size group (SM) was constituted with larvae smaller than $0.1 \mathrm{~g}$ (mean weight $0.061 \pm 0.011 \mathrm{~g}$ ) and large size group (SL) was constituted with larvae larger than $0.1 \mathrm{~g}$ (mean weight $0.148 \pm 0.024 \mathrm{~g}$ ). The third group (US) was not sorted by size (mean weight $0.105 \pm 0.048 \mathrm{~g}$ ). In SM and SL groups, perch were sorted to separate individuals with inflated swim bladders (SB+) and perch with noninflated swim bladders (SB-). In US group, perch with $\mathrm{SB}+$ and $\mathrm{SB}^{-}$were not separated. Sorting was performed in an aqueous solution of sodium chloride $\left(10 \mathrm{~g} \mathrm{~L}^{-1}\right)$ and the anesthetic MS-222 (100 mg L ${ }^{-1}$ ) (Jacquemond 2004). For the initial measurement, 30 perch from each group were euthanized by using an overdose of anesthetic (MS-222; $300 \mathrm{mg} \mathrm{L}^{-1}$ ) then individually weighed by a scale (precision $0.001 \mathrm{~g}$ ) and measured by a caliper (precision $0.01 \mathrm{~cm}$ ). In order to classify the initial weight frequency of each experimental group, the weight of perch were assigned one of the five weight classes ranked as $<0.05 \mathrm{~g}$, $0.05-0.1 \mathrm{~g}, 0.1-0.15 \mathrm{~g}, 0.15-0.2 \mathrm{~g}$, and $>0.2 \mathrm{~g}$. Perch were reared in glass aquaria with a 
volume of $15 \mathrm{~L}$ each, set in a complete recirculating system. The recirculating system was equipped with a lamellar filter for mechanical water purification, a trickling filter for biological water purification and UV lamp. The water flow rate in experimental aquaria was increased gradually from 1.5 to $2.0 \mathrm{~L} \mathrm{~min}^{-1}$. Perch were exposed to a 12-h light (7:0019:00) and 12-h dark (19:00-7:00) photoperiod, with the light intensity as in preexperimental trial. In each group, the stocking density was 5 larvae $\mathrm{L}^{-1}$. The water temperature $\left(21.0 \pm 0.5{ }^{\circ} \mathrm{C}\right)$ and dissolved oxygen level $\left(7.2 \pm 0.6 \mathrm{mg} \mathrm{L}^{-1}\right)$ were monitored daily. Nitrogenous compounds were measured twice a week and did not exceed 0.1 and $0.04 \mathrm{mg} \mathrm{L}^{-1}$ for $\mathrm{N}-\mathrm{NH}_{4}{ }^{+}$and $\mathrm{N}-\mathrm{NO}_{2}{ }^{-}$, respectively. Throughout the experiment, perch were fed with commercial diet (Perla Larva Proactive 4.0) by hand, six times a day (8:00, 10:00, $12: 00,14: 00,16: 00$, and 18:00). Uneaten feed and feces were removed from the experimental aquaria by syphoning every morning before the feeding start. Dead fish were collected daily and ranked as truncated (the posterior damaged or tailed-off) or nontruncated (intact). Truncated individuals were considered as results of type I cannibalism and non-truncated fish as deaths by other reasons. At the end of the experiment, 30 perch from each group were euthanized, individually weighed, and measured as described above. In order to classify the final weight frequency of each experimental group, the weight of perch were assigned one of the seven weight classes ranked as $<0.1 \mathrm{~g}, 0.1-0.2 \mathrm{~g}, 0.2-0.3 \mathrm{~g}$, $0.3-0.4 \mathrm{~g}, 0.4-0.5 \mathrm{~g}, 0.5-0.6 \mathrm{~g}$, and $>0.6 \mathrm{~g}$. All individuals were counted at the end of the experiment and the difference between the initial number of perch and final number of alive and dead perch was considered as results of type II cannibalism (number of lacking fish). Other relevant parameters were assessed as a follows:

- Coefficients of body weight variation $\left[\mathrm{CV}(\%)=100 \cdot \mathrm{SDW} \cdot W^{-1}\right.$, where $W$ is mean body weight and SDW is standard deviation of body weight] were calculated for the first and last day of measurement $\left(\mathrm{CV}_{\mathrm{I}}\right.$ and $\mathrm{CV}_{\mathrm{F}}$, respectively),

- Fulton's condition factor $\left[K=100 \cdot W \cdot L^{-3}\right.$, where $W$ is mean body weight and $L$ is mean total length] was calculated for the first and last day of measurement $\left(K_{\mathrm{I}}\right.$ and $K_{\mathrm{F}}$, respectively),

- Biomass gain $\left[\mathrm{Bs}_{\text {gain }}(\%\right.$ of initial biomass $)=100 \cdot \mathrm{FBs} \cdot \mathrm{IBs}^{-1}$, where $\mathrm{FBs}$ is final biomass and IBs is initial biomass] was calculated at the end of the experiment,

- Overall specific growth rates $\left[\operatorname{SGR}\left(\%\right.\right.$ day $\left.^{-1}\right)=100 \cdot\left(\mathrm{Ln} \cdot W_{\mathrm{F}}-\mathrm{Ln} \cdot W_{\mathrm{I}}\right) \cdot t^{-1}$, where $W_{\mathrm{F}}$ is mean final body weight and $W_{\mathrm{I}}$ is mean initial body weight $(\mathrm{g}) ; t$ is 14 days] were calculated at the end of the experiment.

\section{Statistical analysis}

Normality of parameter distribution was tested by Shapiro-Wilk test and to confirm for homogeneity of variance, Leven's test was used. The data expressed in percentages were arcsin transformed prior to the statistical analysis. All mortality type, final growth parameters, and survival were compared using one-way ANOVA. Significance of differences between groups was estimated using a post hoc LSD Fisher test $(P=0.05)$. For initial weight and length values, a non-parametric Kruskal-Wallis test with pairwise comparisons was used $(P=0.05)$. Size ranking of the fish in each group separately (initial weight rank vs. final weight rank) were tested using Spearman's rank correlation $\left(r_{\mathrm{sp}} ; P=0.05\right)$. Analyses were performed using Statistica software (StatSoft). 


\section{Results}

\section{Growth variables}

At the beginning of the experiment, perch in US group were significantly heavier and longer than perch in SM group, and significantly lighter and shorter than perch in SL group $(P<0.05)$ (Table 1). The initial weight frequency was recorded in SM as $20 \%(<$ $0.05 \mathrm{~g})$ and $80 \%(0.05-0.1 \mathrm{~g})$ (Fig. 1a) whereas in SL, 67\% of perch were belong to $0.1-$ $0.15 \mathrm{~g}$ size group (Fig. 1b). The size frequency in US was more diverse but mostly ranged in $0.05-0.1 \mathrm{~g}(40 \%)$ and $0.1-0.15 \mathrm{~g}(33 \%)$ size groups (Fig. 1c). The coefficient of variation of fish initial body weights $\left(\mathrm{CV}_{\mathrm{I}}\right)$ in SM (17.9\%) and SL (16.4\%) groups were lower than in US group $(45.8 \%)$ (Table 1$)$. The values of initial condition factor $\left(K_{\mathrm{I}}\right)$ differed between all experimental groups, where lowest $K_{\mathrm{I}}$ in SM and highest $K_{\mathrm{I}}$ in SL group were observed $(P<0.05)$ (Table 1$)$.

Difference in mean final body weight $\left(W_{\mathrm{F}}\right)$ and final total length $\left(L_{\mathrm{F}}\right)$ of perch between groups was similar to these established at beginning of the experiment. The mean $\mathrm{W}_{\mathrm{F}}$ of perch was highest in group SL and differed between all groups $(P<0.05)$ (Table 2). The same tendency as $W_{\mathrm{F}}$ in mean $L_{\mathrm{F}}$ of perch in all groups was observed $(P<0.05)$ (Table 2$)$. The final weight frequency was recorded in SM as $3 \%(<0.1 \mathrm{~g}), 29 \%(0.1-0.2 \mathrm{~g}), 51 \%$ $(0.2-0.3 \mathrm{~g})$, and $17 \%(0.3-0.4 \mathrm{~g})$ (Fig. 1d). In the SL group, all perch weighed greater than $0.2 \mathrm{~g}$ and $46 \%$ of them were belong to $0.3-0.4 \mathrm{~g}$ size group (Fig. 1e). The size frequency in US was more diverse but mostly ranged in $0.2-0.3 \mathrm{~g}(32 \%)$ size group (Fig. 1f). A significant size rank correlations were maintained in all groups $\left(r_{\mathrm{sp}}>0.77, P<0.05\right)$ with similar value for SM $\left(r_{\mathrm{sp}}=0.82\right)$, SL $\left(r_{\mathrm{sp}}=0.83\right)$, and US group $\left(r_{\mathrm{sp}}=0.80\right)$. At the end of the experiment, $\mathrm{CV}_{\mathrm{F}}$ increased from 17.9 to $28.2 \%$ in $\mathrm{SM}$ and from 16.4 to $25.3 \%$ in SL, whereas in US group slightly decreased from 45.8 to $37.0 \%$ (Table 2). Difference in $\mathrm{CV}_{\mathrm{F}}$ between both sorted groups and unsorted one was also significant $(P<0.05)$ (Table 2). The values of final condition factor $\left(K_{\mathrm{F}}\right)$ in all experimental groups were not significantly different $(P>0.05)$ (Table 2). During the experiment, perch in SM group had highest SGR $(9.48 \pm 0.34)$, whereas perch in SL group had lowest SGR $(6.95 \pm 0.40)$ (Table 2). Fish biomass gain $\left(\mathrm{Bs}_{\mathrm{gain}}\right)$ was significant higher in both sorted groups than in US $(P<0.05)$. However, the difference in $\mathrm{Bs}_{\text {gain }}$ between SM and SL group was also statistically significant $(P<0.05)$ (Table 2$)$.

Table 1 Initial growth parameters ( $n=30$ fish) of perch (34 dph) according to experimental groups (SM, small size group; $S L$, large size group; US, unsorted group)

\begin{tabular}{llll}
\hline Parameter & Group & \\
\cline { 2 - 4 } & SM & SL & US \\
\hline Body weight $(\mathrm{g})-W_{\mathrm{I}}$ & $0.061^{\mathrm{a}} \pm 0.011$ & $0.148^{\mathrm{b}} \pm 0.024$ & $0.105^{\mathrm{c}} \pm 0.048$ \\
Total length $(\mathrm{cm})-L_{\mathrm{I}}$ & $1.85^{\mathrm{a}} \pm 0.13$ & $2.27^{\mathrm{b}} \pm 0.09$ & $2.06^{\mathrm{c}} \pm 0.24$ \\
Coefficient of IBW $(\%)-\mathrm{CV}_{\mathrm{I}}$ & 17.9 & 16.4 & 45.8 \\
Condition factor $-K_{\mathrm{I}}$ & $0.96^{\mathrm{a}} \pm 0.08$ & $1.26^{\mathrm{b}} \pm 0.09$ & $1.11^{\mathrm{c}} \pm 0.17$ \\
Initial biomass $(\mathrm{g})-\mathrm{IBs}$ & 4.6 & 11.1 & 7.9 \\
\hline
\end{tabular}

$W_{\mathrm{I}}, L_{\mathrm{I}}$, and $K_{\mathrm{I}}$ are expressed as mean $\pm \mathrm{SD}$. Values marked with different superscripts show significant differences $(P<0.05)$ 

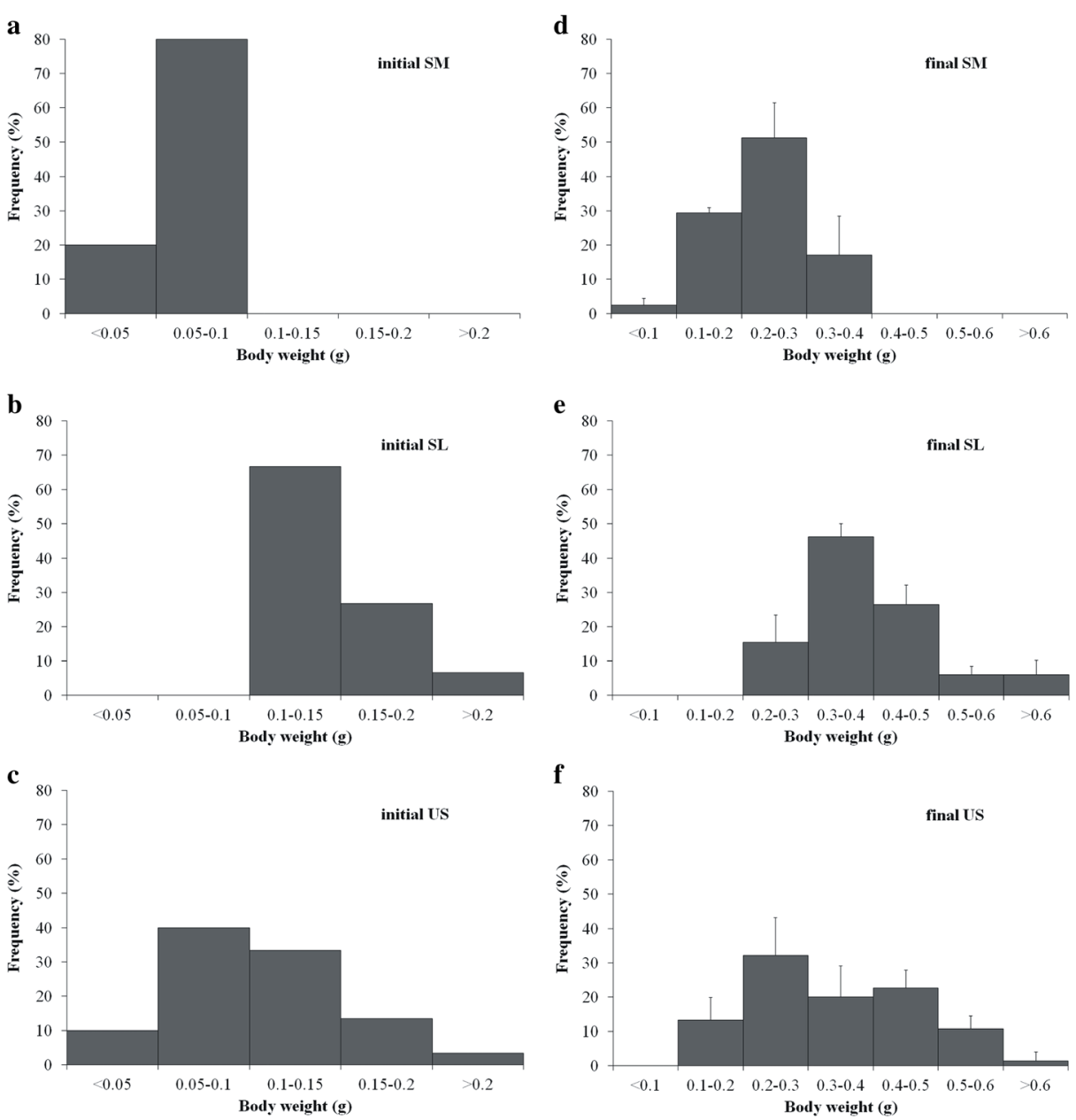

Fig. 1 Comparison of initial $(\mathbf{a}-\mathbf{c})$ and final $(\mathbf{d}-\mathbf{f})$ weight frequency distributions of perch according to experimental groups (SM, small size group; SL, large size group; US, unsorted group). For initial weight distributions, bars represent frequency of 30 perch, whereas for final weight distributions, bars and whiskers are the means and standard deviations of three replicates

\section{Cannibalism and survival}

The significant lower losses to type I cannibalism in SM and SL groups than in US group were observed $(P<0.05)$ (Fig. 2). Losses to type II cannibalism ranged from 2.2 to $4.9 \%$, but not differ significantly between groups $(P>0.05)$ (Fig. 2). At the end of the experiment, survival in SM and SL exceed $92 \%$ and were significantly higher than in US (75.6\%) $(P<0.05)$ (Fig. 3).

\section{Discussion}

Results regarding effect of size sorting on growth parameters in larvae or post-larvae in cultured fish species are limited. For example, size sorting in the pikeperch larvae did not 
Table 2 Final growth parameters ( $n=3$ replicates) of perch post-larvae ( $48 \mathrm{dph}$ ) according to experimental groups ( $S M$, small size group; $S L$, large size group; $U S$, unsorted group)

\begin{tabular}{lccc}
\hline Parameter & Group & & \\
\cline { 2 - 4 } & SM & SL & US \\
\hline Body weight $(\mathrm{g})-W_{\mathrm{F}}$ & $0.231^{\mathrm{a}} \pm 0.011$ & $0.393^{\mathrm{b}} \pm 0.022$ & $0.338^{\mathrm{c}} \pm 0.028$ \\
Total length $(\mathrm{cm})-L_{\mathrm{I}}$ & $2.73^{\mathrm{a}} \pm 0.03$ & $3.24^{\mathrm{b}} \pm 0.05$ & $3.09^{\mathrm{c}} \pm 0.11$ \\
Coefficient of FBW $(\%)-\mathrm{CV}_{\mathrm{F}}$ & $28.2^{\mathrm{a}} \pm 3.4$ & $25.3^{\mathrm{a}} \pm 1.5$ & $37.0^{\mathrm{b}} \pm 2.7$ \\
Condition factor $-K_{\mathrm{F}}$ & $1.13 \pm 0.02$ & $1.16 \pm 0.02$ & $1.15 \pm 0.03$ \\
Final biomass $(\mathrm{g})-\mathrm{FBs}$ & $15.8^{\mathrm{a}} \pm 1.4$ & $27.5^{\mathrm{b}} \pm 2.1$ & $19.0^{\mathrm{c}} \pm 1.0$ \\
Biomass gain $(\%$ of $\mathrm{IBs})-\mathrm{Bs}_{\text {gain }}$ & $344^{\mathrm{a}} \pm 29$ & $256^{\mathrm{b}} \pm 6$ & $233^{\mathrm{c}} \pm 10$ \\
Specific growth rate $\left(\%\right.$ day $\left.^{-1}\right)-\mathrm{SGR}$ & $9.48^{\mathrm{a}} \pm 0.34$ & $6.95^{\mathrm{b}} \pm 0.40$ & $8.35^{\mathrm{c}} \pm 0.60$ \\
\hline
\end{tabular}

All data are expressed as mean \pm SD. Values marked with different superscripts show significant differences $(P<0.05)$

result in increased growth rates, where the growth of fish from the unsorted group did not differ significantly from that of the sorted fish (Szczepkowski et al. 2011). In the presented study, specific growth rate (SGR) of perch was significantly greater in sorted group within small specimens (SM) than in sorted group with large fish (SL), and in unsorted ones (US). Moreover, perch in US group had higher SGR value than perch from SL group. These findings suggest that for perch post-larvae, size sorting lead to better growth in the small fish but not for the large ones. However, significant size rank correlations were maintained during this experiment, where these values were similar for both sorted and unsorted groups. The latter and comparison between initial and final perch weight frequency suggest that the growth potential of perch in all experimental groups was similar. It can be assumed that over a longer

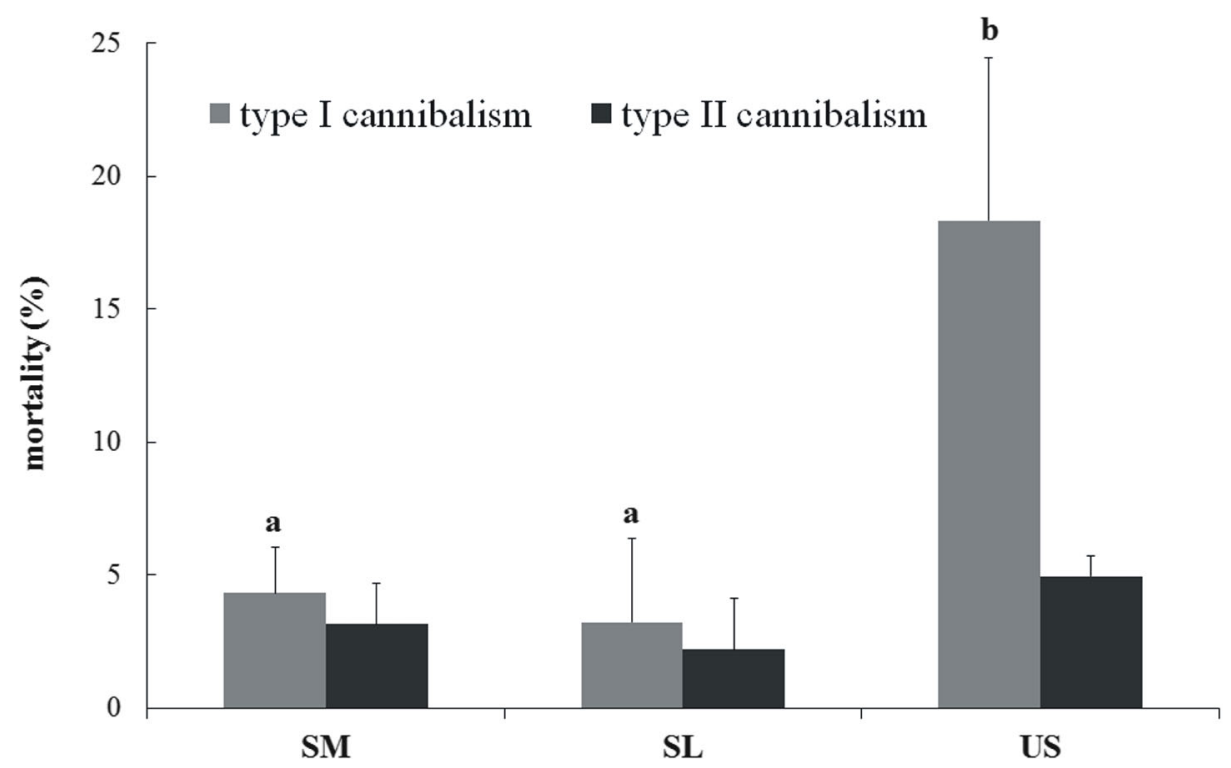

Fig. 2 Respective contributions of incomplete (type I) and complete (type II) cannibalism of perch during 2week experiment, according to experimental groups (SM, small size group; SL, large size group; US, unsorted group). Bars and whiskers are the means and standard deviations of three replicates. Values marked with different superscripts show significant differences $(P<0.05)$ 


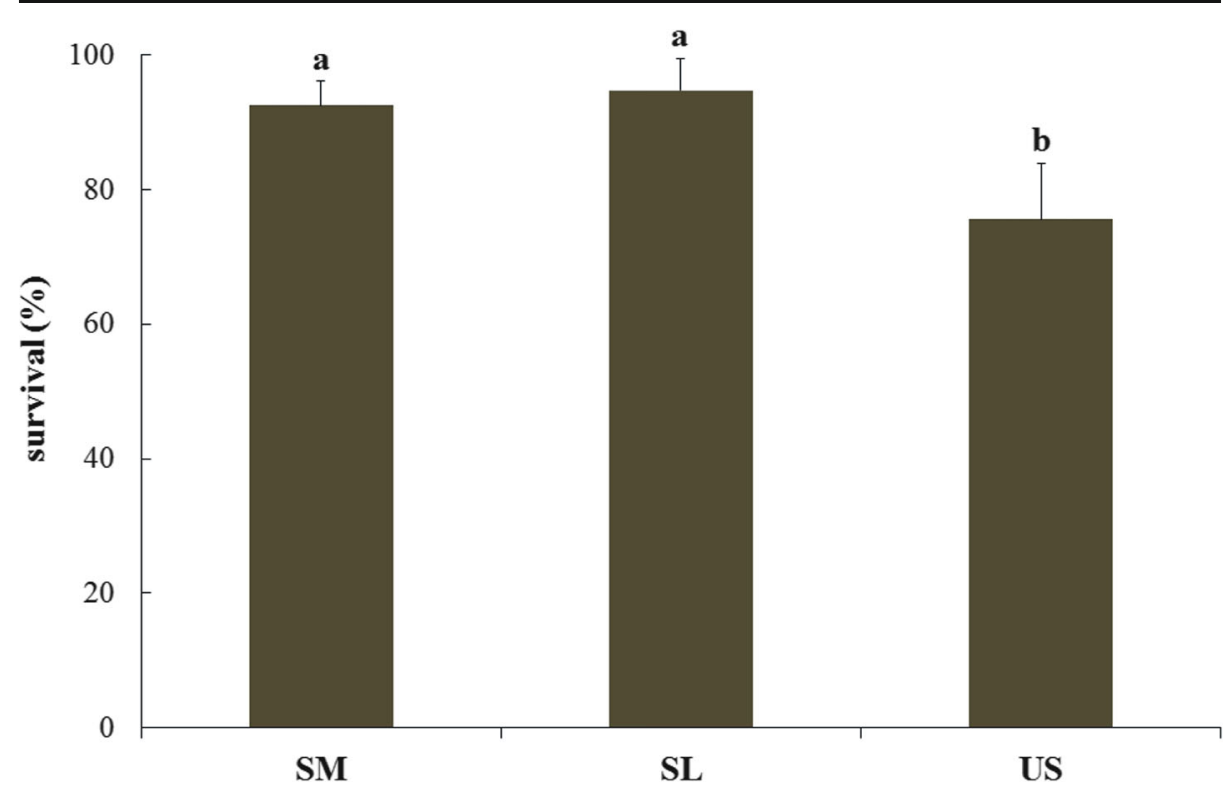

Fig. 3 Survival of perch at the end of 2-week experiment according to experimental groups (SM, small size group; SL, large size group; US, unsorted group). Bars and whiskers are the means and standard deviations of three replicates. Values marked with different superscripts show significant differences $(P<0.05)$

rearing time, the differences in perch growth rate in particular groups would have equalized. The findings of Imsland et al. (2009) in juvenile Atlantic halibut (Hippoglossus hippoglossus) support this expectation, where during 2-month experiment, in the first part of the trial, the fish in the small sorted group had higher growth rate compared with fish in the large sorted and the unsorted groups, whereas no differences in growth rate between all groups were seen in the final period. No effects of size sorting on growth rates in juvenile Eurasian perch (initial BW from 16 to $48 \mathrm{~g}$ ) (Mélard et al. 1995) and in other percid fish species, as pikeperch (initial BW ca. $40 \mathrm{~g}$ ) (Zakęś et al. 2004) and yellow perch, Perca flavescens (initial BW from 5 to $88 \mathrm{~g}$ ) (Wallat et al. 2005) were observed. However, sorting had some a negative impact on juvenile Eurasian perch, where greater increases in body weight were reached in non-sorted fish than sorted ones (Mélard et al. 1996). In the present study, the coefficient of variation (CV) in perch weights for the both sorted groups increased about 65\%, whereas the CV in US showed some reduction, but still remains higher than in SM and SL. In the size sorting experiment in pikeperch larvae, CV in weights increased similarly in sorted and unsorted groups and did not differ significantly between groups (Szczepkowski et al. 2011). Contrary, CV in weights of yellow perch juveniles increased significantly only in the small sorted group whereas in the large sorted specimens and unsorted ones slightly decreased (Wallat et al. 2005). The fact that size ranks were relatively constant in all groups in our study, although CV of weights increased after sorting, may indicate genetic control of observed growth dispersal in perch cohorts or individual differences in metabolism and activity and utilization of food resources, which have been reported previously (Wickins 1985; Doyle and Talbot 1986; Imsland et al. 1997). Anyway, our finding confirms that initial size heterogeneity had very little influence on final size heterogeneity of cultured Eurasian perch (Kestemont et al. 2003; Babiak et al. 2004). 
Size grading is used in the culture of many commercial fish species in an attempt not only to improve growth but also enhance survival and increase biomass gain. However, size grading has failed to improve biomass gain in some cultured species (Jobling and Reinsnes 1987; Baardvik and Jobling 1990; Carmichael 1994). In the present study, significantly higher increases in perch biomass gain in both sorted groups than unsorted ones were recorded. Similar to pikeperch larvae (Szczepkowski et al. 2011), it was due to the higher survival rates of fish in the sorted groups than unsorted one. However, in case of pikeperch larvae, higher survival in sorted groups was primarily the result of decreased losses due to type II cannibalism, whereas in the present study on final perch survival affect only significantly lower losses due to type I cannibalism in both sorted groups, if compared to unsorted ones. In previous studies on percid fish post-larvae, the losses to type II cannibalism largely outnumbered those to type I cannibalism (Baras et al. 2003; Kestemont et al. 2003; Babiak et al. 2004; Szkudlarek and Zakęś 2007; Król and Zakęs 2016). However, in Eurasian perch culture, incomplete cannibalism could affect survival even to 50 days post hatching (Król et al. 2015). Difference in contributions of type I cannibalism between sorted and unsorted groups here can result due to the fact that in our study in unsorted group were some perch with non-inflated swim bladder because European percid fish with non-inflated swim bladders are easy victims for potential cannibals due to the impairment of motor skills (Czesny et al. 2005). Anyway, mitigation of early aggressive behavior (type I cannibalism) is very important for aquaculture of European percid fish species (Król and Zakęś 2016) because type II cannibalism is facilitated by growth advantage gained during type I cannibalism (Baras et al. 2003).

In conclusion, the results of the present experiment indicate that the size sorting of Eurasian perch post-larvae has a positive impact on the effectiveness of their rearing in intensive culture conditions. In proposed procedure however, did not result in unequivocal improvement of growth rates, significant higher biomass gain was noted, directly resulting from higher survival, trough lower losses caused by cannibalism type I. Future research should focus on determining the optimal time of first size sorting of perch post-larvae and perhaps its frequency because, at the end of presented study, high value of CV in fish weights in both previously sorted groups suggest needs for subsequences size sorting during further perch rearing.

Funding information This study was financed by state funds appropriated to University of Warmia and Mazury under the code no. 18.610.003-300.

\section{Compliance with ethical standards}

Conflict of interest The authors declare that they have no conflict of interest.

Ethical approval The study was followed by the authors in accordance with regulations of the international and national guidelines for the care and use of animals.

Open Access This article is distributed under the terms of the Creative Commons Attribution 4.0 International License (http://creativecommons.org/licenses/by/4.0/), which permits unrestricted use, distribution, and reproduction in any medium, provided you give appropriate credit to the original author(s) and the source, provide a link to the Creative Commons license, and indicate if changes were made.

Publisher's Note Springer Nature remains neutral with regard to jurisdictional claims in published maps and institutional affiliations. 


\section{References}

Baardvik BM, Jobling M (1990) Effect of size-sorting on biomass gain and individual growth rates in Arctic charr, Salvelinus alpinus L. Aquaculture 90:11-16

Babiak I, Mandiki SNM, Ratsinjomanana K, Kestemont P (2004) Initial weight and its variation in post-larval Eurasian perch affect quantitative characteristics of juvenile cohorts under controlled conditions. Aquaculture 243:263-276

Baras E, Jobling M (2002) Dynamics of intracohort cannibalism in cultured fish. Aquac Res 33:461-479

Baras E, Kestemont P, Mélard C (2003) Effect of stocking density on the dynamics of cannibalism in sibling larvae of Perca fluviatilis under controlled conditions. Aquaculture 219:241-255

Barki A, Harpaz S, Hulata G, Karplus I (2000) Effects of larger fish and size-grading on growth and size variation in fingerling silver perch. Aquac Int 8:391-401

Batzina A, Drossos I-P, Karakatsoul N (2018) Effects of grading on individual growth and feeding behavior of European seabass Dicentrarchus labra. Aquac Res 49:3759-3768. https://doi.org/10.1111/are.13843

Brzeski VJ, Doyle RW (1995) A test of an on-farm selection procedure for tilapia growth in Indonesia. Aquaculture 137:219-230

Carmichael GJ (1994) Effects of size-grading on variation and growth in channel catfish reared at similar densities. J World Aquacult Soc 25:101-108

Czesny SJ, Graeb BDS, Dettmers JM (2005) Ecological consequences of swim bladder noninflation for larval yellow perch. Trans Am Fish Soc 134:1011-1020

Doyle RW, Talbot AJ (1986) Artificial selection on growth and correlated selection on competitive behavior in fish. Can J Fish Aquat Sci 43:1059-1064

Gunnes K (1976) Effect of size- grading young Atlantic salmon (Salmo salar) on subsequent growth. Aquaculture 9:381-386

Hamza N, Mhetli M, Kestemont P (2007) Effects of weaning age and diets on ontogeny of digestive activities and structures of pikeperch (Sander lucioperca) larvae. Fish Physiol Biochem 33:121-133

Hecht T, Pienaar GA (1993) A review of cannibalism and its implications in fish larviculture. J World Aquacult Soc 24:246-261

Imsland AK, Brix O, Nævdal G, Samuelsen EN (1997) Hemoglobin genotypes in turbot (Scophthalmus maximus Rafinesque): their oxygen affinity properties and relation with growth. Com Biochem Physiol A 116:157-165

Imsland AK, Jenssen MD, Jonassen TM, Stefansson SO (2009) Best among unequals? Effect of size grading and different social environments on the growth performance of juvenile Atlantic halibut. Aquac Int 17:217-227

Jacquemond F (2004) Sorting Eurasian perch fingerlings (Perca fluviatilis L.) with and without functional swim bladder using tricaine methane sulfonate. Aquaculture 231:249-262

Jobling M (1995) Simple indices for the assessment of the influences of social environment on growth performance, exemplified by studies on Arctic charr (Salvelinus alpinus). Aquac Int 3:60-65

Jobling M, Reinsnes TG (1987) Effect of sorting on size-frequency distributions and growth of Arctic charr, Salvelinus alpinus L. Aquaculture 60:27-31

Kestemont P, Jourdan S, Houbart M, Mélard C, Paspatis M, Fontaine P, Cuvier A, Kentouri M, Baras E (2003) Size heterogeneity, cannibalism and competition in cultured predatory fish larvae: biotic and abiotic influences. Aquaculture 227:333-356

Kestemont P, Xueliang X, Hamza N, Maboudou J, Imorou Toko I (2007) Effect of weaning age and diet on pikeperch larviculture. Aquaculture 264:197-204

Kestemont P, Mélard C, Held JA, Dabrowski K (2015) Culture methods of Eurasian perch and yellow perch early life stages. In: Kestemont P, Dabrowski K, Summerfelt RC (eds) Biology and culture of percid fishes. Springer Netherlands, Dordrecht

Król J, Zakęś Z (2016) Effect of dietary L-tryptophan on cannibalism, survival and growth in pikeperch Sander lucioperca (L.) post-larvae. Aquac Int 24:441-451

Król J, Zieliński E (2015) Effects of stocking density and weaning age on cannibalism, survival and growth in European perch Perca fluviatilis larvae. Pol J Natur Sci 30(4):403-415

Król J, Flisiak W, Urbanowicz P, Ulikowski D (2014) Growth, cannibalism and survival relations in larvae of European catfish Silurus glanis (Actinopterygii: Siluriformes: Siluridae) - attempts to mitigate sibling cannibalism. Acta Ichthyol Piscat 44(3):191-199

Król J, Dauchot N, Mandiki SNM, van Cutsem P, Kestemont P (2015) Cannibalism in cultured Eurasian perch Perca fluviatilis (Actinopterygii: Perciformes: Percidae) - implication of maternal influence, kinship and sex ratio of progenies. Acta Ichthyol Piscat 45(1):65-73

Mandiki SNM, Babiak I, Krol J, Rasolo JFR, Kestemont P (2007) How initial predator-prey ratio affects intracohort cannibalism and growth in Eurasian perch Perca fluviatis L larvae and juveniles under controlled conditions. Aquaculture 268:149-155 
Mélard C, Baras E, Kestemont P (1995) Preliminary results of European perch (Perca fluviatilis) intensive farming trials: effect of temperature and size grading on growth. Bull Fr Peche Piscic 336:19-27

Mélard C, Kestemont P, Grignard JC (1996) Intensive culture of juvenile and adult Eurasian perch (P. fluviatilis): effect of major biotic and abiotic factors on growth. J Appl Ichthyol 12:175-180

Petrović S, Bavčević L, Pasarić Z, Mihovilović A (2011) Effects of successive size grading on the growth of juvenile European sea bass (Dicentrarchus labrax L.) at three temperatures. Aquac Res 42:277-287

Policar T, Samarin AM, Mélard C (2015) Culture methods of Eurasian perch during ongrowing. In: Kestemont P, Dabrowski K, Summerfelt RC (eds) Biology and culture of percid fishes. Springer Netherlands, Dordrecht

Popper DM, Golden O, Shezifi Y (1992) Size distribution of juvenile gilthead sea bream (Sparus aurata): practical aspects. Isr J Aquacult-Bamid 44:147-148

Smith C, Reay P (1991) Cannibalism of teleost fishes. Rev Fish Biol Fish 1:41-64

Sunde LM, Imsland AK, Folkvord A, Stefansson SO (1998) Effects of size grading on growth and survival of juvenile turbot at two temperatures. Aquac Int 6:19-32

Szczepkowski M, Zakęś Z, Szczepkowska B, Piotrowska I (2011) Effect of size sorting on the survival, growth and cannibalism in pikeperch (Sander lucioperca L.) larvae during intensive culture in RAS. Czech J Anim Sci 56:483-489

Szkudlarek M, Zakęś Z (2007) Effect of stocking density on survival and growth performance of pikeperch, Sander lucioperca (L.), larvae under controlled conditions. Aquac Int 15:67-81

Teletchea F, Fontaine P (2014) Levels of domestication in fish: implications for the sustainable future of aquaculture. Fish Fish 15:181-195

Toner D (2015) The market for Eurasian perch. In: Kestemont P, Dabrowski K, Summerfelt RC (eds) Biology and culture of percid fishes. Springer Netherlands, Dordrecht

Wallat GK, Tiu LG, Wang HP, Rapp D, Leighfield C (2005) The effects of size grading on production efficiency and growth performance of yellow perch in earthen ponds. N Am J Aquac 67(1):34-41

Wickins JF (1985) Growth variability in individually confined elvers, Anguilla anguilla (L.). J Fish Biol 27:469478

Zakęś Z, Kowalska A, Czerniak S (2004) Effect of sorting on selected rearing factors of pikeperch Sander lucioperca (L.). Arch Pol Fish 12:71-79

Żarski D, Palińska K, Targońska K, Bokor Z, Kotrik L, Krejszeff S, Kupren K, Horváth Á, Urbányi B, Kucharczyk D (2011) Oocyte quality indicators in Eurasian perch, Perca fluviatilis L., during reproduction under controlled conditions. Aquaculture 313:84-91

Żarski D, Horváth Á, Held JA, Kucharczyk D (2015) Artificial reproduction of percid fishes. In: Kestemont P, Dabrowski K, Summerfelt RC (eds) Biology and culture of percid fishes. Springer Netherlands, Dordrecht 